Research Article

\title{
Variables Determinants of Social Performance And Islamic Banking and Conventional variable differentiator Social Performance Among Both Cases in Indonesia
}

\author{
Moch Shulthoni ${ }^{1}$, Siti Maria Wardayati ${ }^{2}$, Ririn Irmadariyani ${ }^{3}$, Hendrawan Santosa Putra ${ }^{4}$ \\ University of Jember, Indonesia
}

\begin{abstract}
This study aims to examine and analyze the effect of risk variables, governance, financial performance, capital structure, asset structure, intermediation and human capital functions on the social performance of sharia commercial banks and conventional commercial banks as well as to test and analyze the influence of risk variables, governance, financial performance, capital structure, asset structure, intermediation functions and human capital towards social differences in performance between conventional and sharia commercial banks. The type of research used in this study is explanatory research, roomates explains the influence of independent variables on the dependent variable and comparative research, the which is research that is used to explain variables that influence the differences in social performance of Islamic banks and conventional commercial banks. The Populations in this study are commercial banks (conventional) and Islamic public banks in Indonesia. The purposive sampling technique was used to Obtain samples items, namely commercial banks (conventional) and sharia commercial banks in Indonesia to publish audited financial reports, annual reports and Reviews those that corporate social responsibility reports submitted between 2013 - 2017. Technical Data analysis used multiple regression and discriminant analysis. The analysis in this study tested the hypothesis. Multiple regression is used to analyze variables that Affect the social performance of conventional commercial banks and Islamic commercial banks. While discriminant analysis is used to analyze what variables influence the social performance of conventional public commercial banks and Islamic banks in Indonesia. Based on the results of the analysis and discussion concluded that (a) the variables of governance, capital structure, asset structure of human capital, risk, intermediation function and financial performance have no significant effect on the social performance of sharia commercial banks; (B) risk and financial performance variables have a significant effect on the social performance of conventional commercial banks. While the variables of governance, capital structure, asset structure of human capital, and intermediation function have no significant effect on the social performance of conventional commercial banks and (c) the variables of risk and financial performance have a significant effect on the performance of social Distinguishing between commercial Islamic banks and conventional commercial banks. While the variables of governance, capital structure, asset structure of human capital, and intermediation function do not Significantly influence between social performance of commercial Islamic banks and conventional commercial banks.
\end{abstract}

Keywords: social performance, banks, sharia, conventional

\section{Background}

In theory the enterprise, the company is viewed as a social institution that operates in the interests of a lot of group interaction. Broadly speaking, these groups consist of shareholders, creditors, employees, customers, governments and society. As social institutions, companies deemed partly responsible for the effects of non-economic terms associated with the company, fulfilling the responsibility to communicate the good financial reporting and accountability must be distributed in an honest and fair to all groups of users of financial statements and the wider community. Enterprise theory sharia have a great concern to the stakeholders at large. According to the theory of sharia enterprise, stakeholders include God, man, and nature. God is the highest and to be the only goal of human life. The second stakeholder theory sharia is a human enterprise which is divided into two groups: directand indirect-stakeholder stakeholders.

The potential of Islamic banking incredible to participate in the role of social intermediation and serve the needs of the poor, who are often overlooked by the traditional banking sector. In the early days, the financial institutions that use a lot of moving Islamic instruments on services for the rural poor.
As with Mit Ghamr in Egypt that will all focus on the economic development, poverty alleviation, cultural learning life-saving among the poor Muslims. However, along with the times, the orientation of Islamic financial institutions (including banks

Sharia) are dominated by the doctrine of the pursuit of high profits (High Profit Maximization Doctrine). At the end of the movement of Islamic financial institutions can only provide services for the wealthy, while the poor

who do not have an understanding of the financial institution is never included, even though they are the majority of Muslims. The phenomenon is not fully reflect the main reason Islamic banking as an institution based on sharia is supposed to reflect the identity and values of Islam.

There is a fundamental difference between conventional banking Islamic banking - which is not only in business practices that do just fine - but also on the values of the main runway (worldview) for the overall strategy and objectives. The values that are in line with the sharia is not only expressed in any transactions to achieve the halal transaction (syaria compliance), but is much broader than that which the role of Islamic banking in the community as a manifestation of the 


\section{Moch Shultoni et al / Variables Determinants of Social Performance And Islamic Banking and Conventional variable differentiator Social Performance Among Both Cases in Indonesia}

beliefs of Islamic values and commitments on issues of unequal distribution of income, poverty, and social justice. Overall, Islamic banking is not only pay attention to the acquisition of profit. Islamic banking is a system that aims to provide a positive contribution to the achievement of socioeconomic goals of the Muslim community, as summarized in Maqasit Sharia As a business entity which sides of sharia, Islamic banking is expected to meet economic goals of Islam, namely ensuring that the wealth can rotate in fair and equitable without mendhalimi those who really deserve it. With different systems run by the conventional commercial banks and Islamic banks will certainly affect the financial performance and social performance of the two banks. Therefore it is necessary to do a study to prove the good performance of both the financial and social side. as has been summarized in the Islamic Maqasit As a business entity which sides of sharia, Islamic banking is expected to meet economic goals of Islam, namely ensuring that the wealth can rotate in a fair and equitable without mendhalimi those who really deserve it. With different systems run by the conventional commercial banks and Islamic banks will certainly affect the financial performance and social performance of the two banks. Therefore it is necessary to do a study to prove the good performance of both the financial and social side. as has been summarized in the Islamic Maqasit As a business entity which sides of sharia, Islamic banking is expected to meet economic goals of Islam, namely ensuring that the wealth can rotate in a fair and equitable without mendhalimi those who really deserve it. With different systems run by the conventional commercial banks and Islamic banks will certainly affect the financial performance and social performance of the two banks. Therefore it is necessary to do a study to prove the good performance of both the financial and social side. namely ensuring that the wealth can rotate in a fair and equitable without mendhalimi those who really deserve it. With different systems run by the conventional commercial banks and Islamic banks will certainly affect the financial performance and social performance of the two banks. Therefore it is necessary to do a study to prove the good performance of both the financial and social side. namely ensuring that the wealth can rotate in a fair and equitable without mendhalimi those who really deserve it. With different systems run by the conventional commercial banks and Islamic banks will certainly affect the financial performance and social performance of the two banks. Therefore it is necessary to do a study to prove the good performance of both the financial and social side.

In 2012, Ekawati and Roziq researching ratio keuangaan performance ratio distinguish groups of Islamic banking and conventional banking group. Results of the research showed that the financial performance of conventional banking group is better than the group of Islamic banking. Roziq and Danurwenda in 2012 studied the effect of good corporate governance to corporate social responsibility through business risk and financial performance of sharia banks in Indonesia. The results of his research found that financial performance does not significantly influence corporate social responsibility but good corporate governance influence on corporate social responsibility.

Social performance of a company has been a concern of government officials, activists, the media, community leaders, employees of the company up to the academics. This phenomenon indicates that CSR is important in

the company's activities. The business world is no longer only concerned with purely financial records, is also making social and environmental aspects as an integral part of the corporate agenda.Overall, Islamic banking is not only pay attention to the acquisition of profit. Islamic banking is a system that aims to provide a positive contribution to the achievement of socio-economic goals of the Muslim community, as summarized in the al-Sharia Maqasid, As a business entity which sides of sharia, Islamic banking is expected to meet economic goals of Islam, namely ensuring that the wealth can rotate in a fair and equitable without mendhalimi those who really deserve it.

Based on the background and the above explanation, the formulation of research problems are; (A) whether the variable risk, governance, financial performance, capital structure, asset structure, intermediation and human capital affects the social performance of Islamic banks; (B) whether the variable risk, governance, financial performance, capital structure, asset structure, intermediation and human capital affects the social performance of a conventional commercial bank; and (c) whether the variable risk, governance, financial performance, capital structure, asset structure, intermediation and human capital affects the social performance differences between conventional and Islamic banks.

\section{Theoretical basis}

\section{Agency theory}

Agency theory explains that in a company there are two parties interact. These parties are the owners of the company (shareholders) and managers of the company. Referred to as the principal shareholder, while the manager, the person who is authorized by shareholders to run the company, called an agent (Jensen and Meckling, 1976). But on the one hand, agents have more information (full information) compared with the principal on the other side, causing the information asymmetry.

Rahmawati et al (2006) explains that the agency theory (agency theory) implies the existence of information asymmetry between managers as agents and owners (in this case is a shareholder) as a principal. This is also confirmed by Pratamasari (2003) that the agency relationship, the manager has information asymmetry against external parties, such as creditors and investors.

More information is owned by the manager may trigger to perform actions in accordance with the wishes and interests to maximize its utility. As for the owners of capital in this case the investor would be difficult to effectively control the actions taken by management because it has little information exists. Therefore, sometimes the specific policies carried out 


\section{Moch Shultoni et al / Variables Determinants of Social Performance And Islamic Banking and Conventional variable differentiator Social Performance Among Both Cases in Indonesia}

by the management company without the knowledge of the owner or investor capital.

Agency theoryusually seen as a conflict of interest (conflict of interest) in accounting and corporate. This means that within the general framework of the agency relationship model shows that managers do to maximize expected utility in order to influence the design of their employment contracts. Principal and agent in business interactions are in fact lead to the same interests, namely wealth, wealth. Finally, accounting becomes a powerful tool to provide maximum benefits to the owners of capital on the one hand, it can also provide the benefits of a capital injection and investment grew, and the linear to the agent of the owners of capital, namely the management company, to manage the company.

Agency relationship that occurs between managers (agents) and owners of capital (principles) in relation to the financial statements (financial statement) is that the assessment of the performance of the manager in charge of the continuity of the company by the owners of capital is based on the net income (net) generated by the manager

\section{Entreprise theory Sharia}

Sarker (1999a) and Yusof and Amin (2004) explains that the purpose of the company is falah namely the achievement of happiness in the world and the hereafter, or the material and spiritual well-being. Achievement falah or welfare according to Islamic law (sharia) is the main focus of human activity in the world. So manufacturers as well as consumers Islami Islami, will try to maximize the welfare of the world as well as prosperity in the hereafter. Should the company with sharia ethics in addition to creating the material prosperity also created mental wellbeing and spiritual welfare (Triyuwono, 2006b).

According to the theory of sharia enterprise, stakeholders include God, man, and nature (Triyuwono, 2006b). God is the highest and to be the only goal of human life. The second stakeholder theory sharia is a human enterprise which is divided into two groups: direct-and indirect-stakeholder stakeholders. Enterprise theory sharia balance egoistic values with altruistic values, the value of the material with the spiritual values and individual values with the congregation. In Islamic law, the equilibrium shape concretely realized in a form of worship, namely zakat (Triyuwono, 2006b). The consequence of this equilibrium value causes islamic enterprise theory not only care about the interests of individuals (in this case the shareholders), but also other parties. Enterprise theory of sharia have accountability wider scope than the entity theory. Accountability in question is the accountability to God, man, and nature (Triyuwono, 2006a: $35)$.

\section{Islamic Bank}

Mannan (1997) explains that the values of sharia in a micro perspective requires that all funds raised in the Islamic banking system is managed according to the principles include (a) Siddiq, (b) sermons (c). mandate (d) fathanah. The values of sharia in a macro perspective means that Islamic banking Research Hypothesis: should contribute to the welfare of the community by referring to (a) the rules of zakat, (b) the prohibition of usury rules, (c) rules banning gambling or gambling and (d) rule banning gharar. According to Karim (2004) and Antonio (2001) basically the products offered by Islamic banking can be divided into three major parts, namely: (a) the product consists of the distribution of funds; financing with the principle of sale (financing murabaha, salam and istishna); financing with principles of lease (Ijara financing); financing with the principle of sharing (Musharaka financing and mudaraba) and a complementary agreement (hawalah, Rahn, qardh, wakalah and kafalah), (b) the product consists of a collection of funds; fund with wadiah principle and the principle of Mudharabah (mudaraba mutlaqah and muqayyadah) and a complementary agreement wakalah and (c) the product consists of banking services Sharf and Ijara.

\section{Conventional Banks}

Under the law number 10 of 1998 conventional bank is a bank conducting conventional business in its activities providing services in payment traffic. Martono (2002) explains that the conventional principles used there are two methods, namely: (a) set rates as price, both for products such as savings deposits, time deposits and loan products (credit) givenby certain interest rate and (b) for other bank services, the bank using or applying various nominal fee or a certain percentage. costing system is called fee-based. Onbank konvensioal, The owner's interest is to obtain a compensation fund in the form of savings interest while in tow, while the interests of shareholders are among them obtain optimal spread between deposit rates and lending rates (interest optimize the difference).

\section{Conceptual Framework and Research Hypotheses}

Based on the explanation of the relationship between variables as above then drafted a conceptual framework first research model to explain the variables which serves as the independent variables and the dependent variable. With the preposition which is based on theoretical studies and empirical studies will be clear how many hypotheses to be compiled, the variables contained in each of these hypotheses and how the relationships between variables.

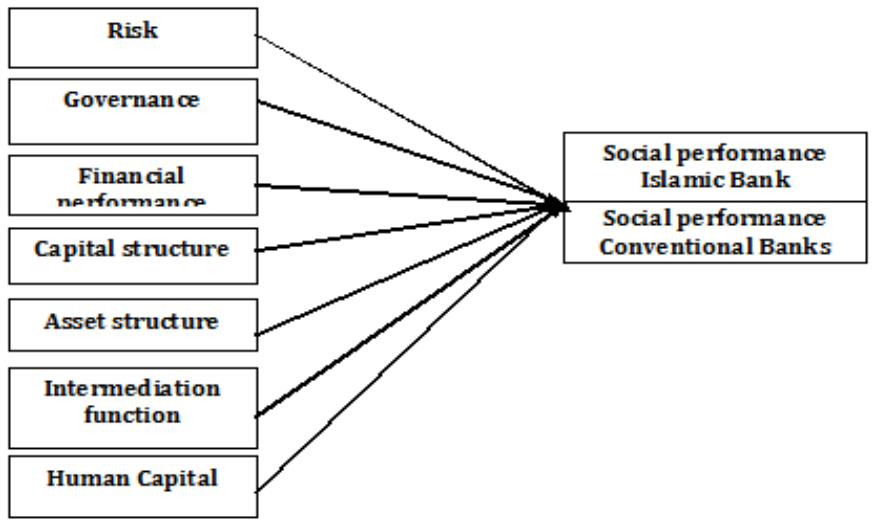

Figure 1 Conceptual Framework Research

H1 = The risk of a significant effect on the social 
performance of Islamic banks and conventional banks as well as a significant influence on social performance to distinguish between Islamic banks and conventional banks

$\mathrm{H} 2=$ Governance a significant effect on social performance distinguish between Islamic banks and conventional banks as well as a significant influence on social performance to distinguish between Islamic banks and conventional banks

H3 = Significant influence financial performance social performance distinguish between Islamic banks and conventional banks as well as a significant influence on social performance to distinguish between Islamic banks and conventional banks

$\mathrm{H} 4$ = Significant influence capital structure differentiate between the social performance of Islamic banks and conventional banks as well as a significant influence on social performance to distinguish between Islamic banks and conventional banks

H5 = Significant influence asset structure differentiate between the social performance of Islamic banks and conventional banks as well as a significant influence on social performance to distinguish between Islamic banks and conventional banks

H6 = The intermediation function have a significant effect on social performance to distinguish between Islamic banks and conventional banks as well as a significant influence on social performance to distinguish between Islamic banks and conventional banks

$\mathrm{H7}$ = Significant effect of human capital distinguish between the social performance of Islamic banks and conventional banks as well as a significant influence on social performance to distinguish between Islamic banks and conventional banks

\section{Research methods}

The research method used in this research is quantitative method. Type of this research is explanatory research which types of studies that examined the effect of independent variables (risk, governance, financial performance, capital structure, asset structure, intermediation and human capital to the dependent variable of the social performance of a conventional bank and syariah and comparative research is the type of research that aims to explain the social performance variables distinguishing between conventional and sharia banks through hypothesis testing.

Data used in this study is a secondary form of ratios - financial ratios and financial data relevant to the independent and dependent variables to be studied. This secondary data obtained from conventional commercial bank's financial statements and sharia banks are audited and published in the annual report (annual report) beginning in 2013-2017.

The population in this study were commercial banks (conventional) and sharia banks in Indonesia. Through data collection techniques, sampling purposive sample obtained in this research are commercial banks (conventional) and sharia banks in Indonesia to publish audited financial statements, annual report and submit reports on corporate social responsibility between the years 2013-2017.

Technical analysis of data using multiple regression and discriminant analysis. The analysis in this research hypothesis testing. Multiple regression was used to analyze the variables variables that affect social performance with conventional banks and Islamic banks. While the discriminant analysis was used to analyze the variables that influence what social performance difference with conventional banks and Islamic banks in Indonesia.

\section{Results and dicussion}

In the first study models, PLS is used to test and analyze the effect of variable risk, financial performance, capital structure, asset structure, intermediation and human capital to the social performance of Islamic banks

Table 1. Research Model 1: Result of Path Coefficients

\begin{tabular}{|c|c|c|c|c|c|}
\hline & $\begin{array}{l}\text { Original } \\
\text { Sample } \\
\text { (O) }\end{array}$ & $\begin{array}{l}\text { Sample } \\
\text { Mean (M) }\end{array}$ & $\begin{array}{l}\text { Standard } \\
\text { Deviation } \\
\text { (STDEV) }\end{array}$ & $\begin{array}{l}\text { T Statistics }(\mathrm{O} \\
\text { / STDEV) }\end{array}$ & $\begin{array}{l}\mathrm{P} \\
\text { values }\end{array}$ \\
\hline Fungtion intermediation $->$ Social Performance & -0243 & -0293 & 0170 & 1,431 & 0153 \\
\hline Human Capital -> Social Performance & -0013 & 0022 & 0325 & 0039 & 0969 \\
\hline Financial Performance -> Social Performance & 0268 & 0285 & .553 & 0484 & 0629 \\
\hline Risk -> Social Performance & 0109 & 0121 & 0505 & 0215 & 0830 \\
\hline Asset Structure -> Social Performance & -0020 & -0027 & 0152 & 0131 & 0896 \\
\hline Capital Structure -> Social Performance & 0051 & 0043 & 0112 & 0458 & 0647 \\
\hline Governance -> Social Performance & 0136 & 0.0186 & 0196 & 0696 & 0487 \\
\hline
\end{tabular}

Source: PLS output 


\section{Moch Shultoni et al / Variables Determinants of Social Performance And Islamic Banking and Conventional variable differentiator Social Performance Among Both Cases in Indonesia}

structure, intermediation, human capital and governance no significant effect on the social performance of Islamic banks In the second study models, PLS is used to test and analyze Table 2. Research Model 2: Result of Path Coefficients

\begin{tabular}{|l|l|l|l|l|l|}
\hline & $\begin{array}{l}\text { Original } \\
\text { Sample (O) }\end{array}$ & $\begin{array}{l}\text { Sample } \\
\text { Mean (M) }\end{array}$ & $\begin{array}{l}\text { Standard } \\
\text { Deviation } \\
\text { (STDEV) }\end{array}$ & $\begin{array}{l}\text { T Statistics (O } \\
\text { / STDEV) }\end{array}$ & $\begin{array}{l}\text { P } \\
\text { values }\end{array}$ \\
\hline Capital Structurel -> Social Performance & 0078 & 0084 & 0049 & 1587 & 0113 \\
\hline Intermediation Fungtion-> Social Performance & 0021 & 0022 & 0057 & 0359 & 0720 \\
\hline Financial Performance -> Social Performance & 0250 & 0256 & 0125 & 2,005 & 0045 \\
\hline Risk -> Social Performance & 0360 & 0362 & 0140 & 2577 & 0010 \\
\hline Asset Structure -> Social Performance & 0061 & 0066 & 0045 & 1,352 & 0177 \\
\hline Capital Structure -> Social Performance & -0013 & -0018 & 0083 & 0152 & 0879 \\
\hline Governance -> Social Performance & -0176 & -0172 & 0145 & 1,215 & 0225 \\
\hline
\end{tabular}

Source: PLS output

Based on the test results of path coefficient was found that the risk variables and financial performance significantly influence the social performance of conventional banks. While the capital structure, asset structure, intermediation, human capital and governance bepengaruh not significant to the social performance of conventional banks

In the third research models, discriminant analysis was used to

Table 3. Test Wilks' Lambda

\begin{tabular}{|l|l|l|l|l|}
\hline Test of Function (s) & Wilks' Lambda & Chi-square & df & Sig. \\
\hline 1 & .381 & 117.705 & 2 & 0,000 \\
\hline
\end{tabular}

produce numbers Wilks' lambda of 0.381 , chi-square 117.705 and significance level of 0.000 indicates that there are significant differences between the social performance of Islamic banks and conventional banks social performance

Analysis of the test results of stepwise discriminant statistics

Table 4 Test Stepwise

\begin{tabular}{|c|c|c|c|c|c|c|c|c|c|}
\hline \multirow[b]{3}{*}{ Step } & \multirow[b]{3}{*}{ Entered } & \multicolumn{8}{|c|}{ Wilks'Lambda } \\
\hline & & \multirow[b]{2}{*}{ statistics } & \multirow[b]{2}{*}{ DF1 } & \multirow[b]{2}{*}{ DF2 } & \multirow[b]{2}{*}{ df3 } & \multicolumn{4}{|l|}{ Exact $\mathrm{F}$} \\
\hline & & & & & & statistics & DF1 & DF2 & Sig. \\
\hline 1 & $\begin{array}{l}\text { Financial } \\
\text { performance }\end{array}$ &, 66 & 1 & 1 & 123.0 & 62.77 & 1 & 123.0 &, 00 \\
\hline 2 & Risk &, 38 & 2 & 1 & 123.0 & 99.07 & 2 & 122.0 &, 00 \\
\hline
\end{tabular}

Based on the results of the stepwise method by iterating twice earned two significant variables differentiate among social performance of Islamic banks and conventional banks because of the significance value less than 0.05 , the variable risk and financial performance.

Based on the test results showed that the variable stepwise risk and financial performance have significant influence in social performance differ between conventional banks and Islamic banks. While the capital structure, asset structure, intermediation, human capital and governance bepengaruh not significant in distinguishing between social performance of conventional and sharia banks.

\section{Conclusion}

Based on the results of research and discussion, the conclusions of this study are no indepeneden variables that examine and analyze the effect of variable risk, financial performance, capital structure, asset structure, intermediation and human capital which differentiate between social performance of Islamic banks and conventional banks.

Based on the test the average difference between groups such as the table below. the effect of variable risk, financial performance, capital structure, asset structure, intermediation and human capital to the social performance of a conventional bank. 
Commercial Bank. www.bi.go.id

[2] www.bi.go.id

2018. Statistics Islamic Banks.

[3] Chaganti, R. and F. Damanpour. 1991. Institutional Ownership, Capital Structure, And Firm Performance. Strategic Management Journal, 12 (7), 479-491.

[4] Dendawijaya. 2003. Banking Management, Second Edition. Ghalia Indonesia, Jakarta

[5] Ekaningsih, Lely Ana Ferawati and Roziq, Ahmad. Distinguishing 2012. The ratio Ratio Keuangaan Performance Group Islamic Banking and Conventional Banking Group. Journal of Economics, Finance and Management (JEAM) Faculty of Economics and Business, University of Jember. Vol. 11 No. 1 in 2012.

[6] Fadholi, Amri Dziki. 2015. Effect of Financing Murabaha, Musharaka and Mudaraba terdahap Profitability Islamic Banks. Journals. muhammadiyah Surakarta university

[7] Fahmi, Irham. 2012. Analysis Report Keuangan.Cetakan 2nd. Alfabeta, Bandung

[8] Hasibuan, Malay SP2000. Basics of Banking. Earth Literacy, Jakarta

[9] Januarti. 2002. CAMEL proxy variables and characteristics Other Bank forPredicting Bankruptcy Bank in Indonesia, junal Business Strategy, Vol.10, December, .www.ejournal.undip.ac.id / index.php / jbs accessed on 18 February 2017, Page 1-10

[10] Hamdani, A. and Y. Yafeh. 2010. As the Minority Shareholders Institutional Investors: Do They Matter When Is Concentrated Ownership? Retrieved From: http://Ssrn.Com/Abstract $1 / 41641138 \quad$ orAccessed http://Dx.Doi.Org/10.2139/Ssrn.1641138 10:10:11

[11] Jensen, Michael C. and WH Meckling. 1976. The Theory Of The Firm: Managerial Behavior, Agency Cost And Ownership Structure. Journal of Financial Economics, 3, 305-360.

[12] Jensen, MC 1986. Agency Costs of Free Cash Flow, Corporate Finance, And Takeovers. The American Economic Review, 76, 323-329.

[13]Lee, Sanghoon. 2008. Ownership Structure And Firm Performancce: Evidence From Panel Data Of South Korea. Working Paper \# 17. University Of Utah.

[14] Lin, YR and XM Fu. 2017. Does Influenze Institutional Ownership Firm Performance? Evidance from China. International Review of Economics and Finance, 49, 1757.

[15] Manzaneque, M., E. Merino and AM Priego. 2016. The Role Of Institutional Shareholders And Directors As Owners And The Financial Distress Likelihood. Evidence From A Concentrated Ownership Context. European Management Journal, 34 (4), 439-451.
[16] Mardiyanto, Handono, 2009. Highlights of Financial Management. Jakarta: Grasindo Munawir, S. 2012. Analysis of Financial Information, Liberty, Yogyakarta

[17]Financial Fervices Authority. Statistics 2018. Conventional Commercial Bank. www.ojk.go.id

[18]

2018. Statistics Islamic

Banks.www.ojk.go.id

[19] Roziq, Ahmad and Danurwenda, Herdian Nisar.2012. Influence Of Good Corporate Governance Corporate Social Responsibility Through Business Risk and Financial Performance In Islamic Banks in Indonesia.

[20] Sucipto. 2003. Assessment of Financial Performance. Journal of Accounting, Bachelor Degree

[21] Taswan. 2008. Accounting for Banks. UPP STIM YKPM.

[22] Thomsen, S. and T. Pedersen. 2000. Ownership Structure And Economic Performance In The Largest European Companies. Strategic Management Journal, 21 (6), 689705 .

[23] Yahya, Rizal. 2014. Islamic Banking Accounting (Theory and Practice of Contemporary). PT. Salemba. Jakarta

[24] Wild, John J, Subramanyam, KR and Halsey, Robert F. 2004. Financial Statement Analysis. McGraw Hill. USA 